\title{
Enzyme Unit per Meter Squared
}

National Cancer Institute

\section{Source}

National Cancer Institute. Enzyme Unit per Meter Squared. NCI Thesaurus. Code C156467.

A unit of concentration (catalytic activity) equal to one enzyme unit of substance per one square meter of surface area. 